\title{
CORRELATION OF THE CHEMICAL COMPOSITION OF ENAMEL AND ORAL FLUID WITH INTACT TEETH AND CERVICAL CARIES
}

\author{
Iryna Zabolotna, Svitlana Yarova, Olena Genzytska \\ Department of Dentistry №2, Donetsk National Medical University, Liman, Ukraine
}

\begin{abstract}
INTRODUCTION: Caries is a widespread polyetiological disease. Oral fluid properties and composition play an important role in its development and progression.

ОвJеCтIVEs: The aim of this study was to present the ability of different voxel sizes in identifying osseous defects of mandibular condyle using CBCT images.

MATERIAL AND Methods: We determined $\mathrm{Ca}^{2+}, \mathrm{PO}_{4}^{3-}$, and $\mathrm{SO}_{4}^{2-}$ using spectrophotometric method, $\mathrm{Na}^{+}, \mathrm{K}^{+}$, $\mathrm{Al}$ by atomic emission spectrometry, $\mathrm{Mg}^{2+}, \mathrm{Zn}$ by atomic absorption spectrometry, $\mathrm{Cl}^{-}$using chloride-selective electrode of $\mathrm{pH}$-meter in oral fluid of 22 patients divided into two groups: case DMFT $=1.45 \pm 0.48$ and control $\mathrm{DMFT}=0$. Correlation of oral fluid and cervical enamel chemical composition of 19 extracted teeth was made. RESULTS: The values of molar coefficients were high in intact teeth enamel: $\mathrm{P} / \mathrm{Ca}$ by $10 \%, \mathrm{Mg} / \mathrm{Ca}$ by $82 \%$, and $\mathrm{K} / \mathrm{Na}$ by $50 \%$. The following values were lower: $\mathrm{Ca} / \mathrm{P}$ by $10 \%, \mathrm{Ca} / \mathrm{Cl}$ by $16 \%$, and $\mathrm{Mg} / \mathrm{P}$ by $43 \%(p \leq 0.05)$. The distinctive feature of correlation of oral fluid and enamel chemical composition in the control group patients was the presence of average $\mathrm{Mg}^{2+}$ bond strength: direct with $\mathrm{Cl}^{-}, \mathrm{K}^{+}$, and $\mathrm{Na}^{+}$, and inverse with $\mathrm{Ca}^{2+}$ and $\mathrm{PO}_{4}^{3-}(p<0.0001)$. The correlation between molar coefficients of oral fluid and enamel of patients with intact hard tissues was distinguished by the presence of high direct correlation of $\mathrm{Mg}^{2+} / \mathrm{Ca}^{2+}$ with $\mathrm{PO}_{4}^{3-} / \mathrm{Ca}^{2+}$, moderate inverse correlation of $\mathrm{Ca}^{2+} / \mathrm{Cl}^{-}$with $\mathrm{PO}_{4}^{3-} / \mathrm{Ca}^{2+}$, and the absence of moderate correlation of $\mathrm{Mg}^{2+} / \mathrm{Ca}^{2+}$ with $\mathrm{Ca}^{2+} / \mathrm{PO}_{4}^{3-}(p<0.0001)$. Conclusions: Revealed correlations may be used to diagnose cervical caries and control the effectiveness of its prevention in terms of mixed saliva over time.
\end{abstract}

KEY WORDS: dental caries, saliva, spectrometry, scanning electron microscope, analytical chemistry.

J Stoma 2020; 73, 6: 283-288

DOI: https://doi.org/10.5114/jos.2020.101875

\section{INTRODUCTION}

Dental caries is a widespread polyetiological disease, and cervical form of this pathology represents a significant part of all clinical cases diagnosed in the group of $30-50$ years of age $[1,2]$. Since the teeth are in constant contact with saliva, the composition and properties of oral fluid (OF) play an important role in the onset and progression of this disease [1, 3-6]. The intensity of caries is in negative correlation with the indicators of mineral metabolism in OF [7]. The mineralizing properties of saliva determine the resistance to caries after teeth eruption, contribute to the maintenance of their physical and chemical integrity, and the leading role belongs to calcium and phosphorus, which are the main structure-forming elements of enamel hydroxyapatite [3, 5-9].
JOURNAL OF STOMATOLOGY CZASOPISMO STOMATOLOGICZNE
Address for Correspondence: Olena Genzytska, Dental Department №2, Donetsk National Medical University, Bulvar Mashinobydivelnikiv 39a, building 6, room 6103, Kramatorsk, 84313, Ukraine, e-mail: Blacky3000@ukr.net

ReCEIVED: 15.09 .2020 • ACCEPTED: 24.11.2020 • PUBLISHED: 30.12.2020 
Enamel is capable of reversible isomorphic replacement of its ions with OF ions without destroying the crystal structure and abrupt changes in properties. It minimizes its demineralization and enhances remineralization, which is carried out by saliva supersaturated with ions relating to tooth enamel [10]. Based on macro- and microelement state of hard tissues of the teeth, one can assess their mineralization [11]. Saliva is a perspective substance for early detection of diseases of the oral cavity and assessment of the effectiveness of prophylactic agents applied [12]. Therefore, it is necessary to study the chemical composition of both tooth tissues and biological fluids, which wash the teeth to prevent demineralization processes [13]. If there is a correlation between the indicators for OF composition, the mineral state of enamel can be established.

\section{OBJECTIVES}

The purpose of the study was to determine the chemical composition and the level of OF mineralization index in patients with cervical caries and clinically intact hard tissues as well as to find correlations between the indicators of cervical enamel and OF, and identify their possible role in the development of cervical caries of teeth.

\section{MATERIAL AND METHODS}

Twenty-two patients (11 men, 11 women) without somatic pathology (mean age, $23.39 \pm 5.61$ years) participated in clinical and laboratory studies. According to the results of clinical examination, two groups (11 pts./11pts.) were formed to accomplish assigned tasks: case - DMFT (decayed missing filled teeth $)=1.45 \pm 0.48$ ((ICDAS (International Caries Detection and Assessment System) $=$ group 3 (localized enamel breakdown [without clinical visual signs of dentinal involvement] seen when wet and after prolonged drying); control: DMFT $=0$ ((ICDAS $=$ group 0 (sound tooth surface: no evidence of caries after $5 \mathrm{sec}$. of air drying)). The absence of bad habits, diseases of periodontal tissues and oral mucosa, orthopedic and orthodontic structures in the oral cavity were the criteria for inclusion. The work was performed in accordance with the principles of WMA Declaration of Helsinki "Ethical Principles for Medical Research involving Human Subjects", order No. 690 of the Ministry of Health of Ukraine (dated September 23, 2009) and approved by the Bioethics Commission of Donetsk National Medical University. Before being involved in the survey, all the participants were provided with written informed consent.

The material for laboratory studies was unstimulated OF, which was collected from 10 till 12 o'clock. Brushing teeth, eating, drinking, and smoking were forbidden 2 hours before the beginning of the research. Previously, the oral cavity was rinsed twice thoroughly with distilled water. $20 \mathrm{ml}$ of saliva was collected into a sterile plastic test tube with a lid and was examined in the laboratory of the Department of Chemical Metrology of Kharkov National University. Spectrometry method was applied to determine phosphate ions, ionized calcium, and $\mathrm{SO}_{4}^{2-}$ $\left(\mathrm{PO}_{4}^{3-}\right.$ with ammonium molybdate at $\lambda=340 \mathrm{~nm}, \mathrm{Ca}^{2+}$ with o-cresolphthalein at $\lambda=570 \mathrm{~nm}, \mathrm{SO}_{4}^{2-}$ with methylene blue at $\lambda=650 \mathrm{~nm}$ ). The emission variant of atomic emission spectrometry was used to detect potassium and sodium (for $\mathrm{K}^{+} \lambda=766.5 \mathrm{~nm}$, monochromator slit width is $0.5 \mathrm{~nm}$; for $\mathrm{Na}^{+} \lambda=589.0 \mathrm{~nm}$, monochromator slit width is $0.1 \mathrm{~nm})$. Inductively coupled plasma atomic emission spectrometry $(\lambda=308.22 \mathrm{~nm})$ was used to evaluate aluminum. Magnesium and zinc were defined using atomic absorption spectrometry (for $\mathrm{Mg}^{2+}$, $\lambda=285.2 \mathrm{~nm}$, amperage $-5 \mathrm{~mA}$, photoelectron multiplier $-1.3 \mathrm{kV}$, monochromator slit width $-0.1 \mathrm{~nm}$; for $\mathrm{Zn}^{2+}, \lambda=213.9 \mathrm{~nm}$, amperage $-5 \mathrm{~mA}$, photomultiplier $-1.3 \mathrm{kV}$, monochromator slit width $-0.1 \mathrm{~nm}$ ). Chloride ions were identified using an ELIS $131 \mathrm{Cl}$ chloride selective electrode, with an EVL-1 ME reference electrode connected to a $\mathrm{pH}$ meter. The samples for the content of $\mathrm{K}^{+}, \mathrm{Na}^{+}$, and $\mathrm{Mg}^{2+}$ were diluted with bidistilled water by 1,000 times. The molar coefficients were calculated as the ratio of the amounts of chemical analytes in the supernatant. The level of OF mineralization potential was calculated as the ratio of the rate of salivation to the concentration of ionized calcium, where values of 0.5 and higher were regarded as high intensity of mineralization, and values less than 0.5 as decreased [9]. The salivation rate was determined in $\mathrm{ml} / \mathrm{min}$ according to the formula: the amount of taken OF/collection time [14].

We performed the correlation of chemical composition of the oral fluid and the enamel of cervical region of 19 teeth of both jaws, which were removed for clinical indications (12 clinically intact, 7 with cervical caries) in patients between 25 and 54 of age. The teeth were extracted for orthodontic indications. JSM-6490 LV focused beam electron microscope (scanning) with system of energy-dispersive X-ray microanalysis INCA Penta FETx3 (OXFORD Instruments, England) was used. The chemical composition of 162 areas of the cervical enamel was determined as a percentage of weight amounts of carbon, oxygen, calcium, phosphorus, sodium, magnesium, sulfur, chlorine, zinc, potassium, and aluminum [15]. Replication measurements were averaged in one sample before statistical analysis. The study was conducted at the base of Donetsk Institute of Physics and Technology of the National Academy of Sciences of Ukraine.

\section{STATISTICAL ANALYSIS}

Statistical analysis was performed using Statistica 12.0 computer program (3BA94C4ED07A). To verify the presence of a relationship between the variables, the correlation analysis was carried out (Pearson's parametric correlation method) based on the determination 
of parametric Brave-Pearson coefficient $(r)$, with 95\% confidence level. The reliability of obtained results was assessed using Student's $t$-test, and the correlation between the indicators based on Student's $t$-test was determined with $Z$-test (Fisher's $Z$-test). The differences were considered statistically significant at $p \leq 0.05$. The significance of the differences between the groups was evaluated based on an analysis of variance.

\section{RESULTS}

The comparative analysis of the content of chemical analytes in OF was carried out at the first stage (Table 1). Since the indicators changed in opposite directions in the groups, it became possible to increase the significance of the differences by calculating their molar ratios (Table 2).

Obtained results indicated the absence of significant differences in the content of chemical analytes and molar coefficients in OF $(p>0.05)$. Mineralization of mixed saliva was significantly higher $(0.93 \pm 0.29)$ in the control group than in the case group $(0.67 \pm 0.26)$ by $1.39 \pm$ 0.08 times $(p=0.006)$. This indicator was in high directly proportional correlation with the coefficient of dispersion of OFs' impedance and the rate of salivation in all patients $(p \leq 0.05)$ [14]. High inverse correlation was found between the coefficient of OF impedance variance and the amount of $\mathrm{Cl}^{-}(r=-0.767, p=0.006)$ in the control group [14].

The data on chemical composition of the cervical enamel of teeth with caries and intact hard tissues is presented in a previous work [15]. Inverse proportional correlation was shown in the cervical region of the samples of the main and control groups: high - between carbon and oxygen $(r=-0.7311)$, carbon and phosphorus $(r=-0.7573)$; moderate - between oxygen and aluminum $(r=-0.5288), p<0.0001$. Directly proportional correlation was determined: high - between calcium and phosphorus ( $r=0.7635)$; moderate - between aluminum and carbon $(r=0.5819), p<0.0001$.

The results of molar coefficients calculations in the investigated groups are presented in Table 3.

Significant differences were determined in the values of $\mathrm{Ca} / \mathrm{P}, \mathrm{P} / \mathrm{Ca}, \mathrm{Ca} / \mathrm{Cl}, \mathrm{Mg} / \mathrm{Ca}, \mathrm{Mg} / \mathrm{P}, \mathrm{K} / \mathrm{Na}(p \leq 0.05)$. The ratios of chemical analytes were large in the enamel of the samples with clinically intact hard tissues: $\mathrm{P} / \mathrm{Ca}-$ by $10 \%, \mathrm{Mg} / \mathrm{Ca}-$ by $82 \%, \mathrm{~K} / \mathrm{Na}$ - by $50 \%$; lower: $\mathrm{Ca} / \mathrm{P}$ - by $10 \%, \mathrm{Ca} / \mathrm{Cl}$ - by $16 \%, \mathrm{Mg} / \mathrm{P}$ - by $43 \%$ ( $p \leq 0.05)$. High correlation was found between molar coefficients in the cervical enamel: very high directly proportional correlation between $\mathrm{Mg} / \mathrm{Ca}$ and $\mathrm{Mg} / \mathrm{P}(r=0.9806)$; moderate inversely proportional correlation between $\mathrm{Mg} / \mathrm{Ca}$ and $\mathrm{Na} / \mathrm{Mg}(r=-0.5087)$, and $\mathrm{Mg} / \mathrm{P}$ and $\mathrm{Ca} / \mathrm{Mg}$ $(r=-0.6618), p<0.0001$.

The correlation analysis was performed to verify the presence of a relationship between the chemical composition of OF and cervical enamel at the second stage of the study. The results of the revealed correlation between the indicators of moderate and high strength are presented in Table 4.

The distinctive feature of the relationships in the control group was the presence of moderate degree of $\mathrm{Mg}^{2+}$ correlation: directly proportional correlation with $\mathrm{Cl}^{-}$

TABLE 1. Chemical analytes in $O F, X \pm m$

\begin{tabular}{|l|c|c|c|}
\hline \multicolumn{1}{|c|}{ Chemical analytes } & Case group & Control group & p-value \\
\hline $\mathrm{K}^{+}, \mathrm{mmol} / \mathrm{l}$ & $22.20 \pm 5.10$ & $24.60 \pm 5.20$ & 0.378 \\
\hline $\mathrm{Na}^{+}, \mathrm{mmol} / \mathrm{l}$ & $11.80 \pm 10.70$ & $18.30 \pm 15.70$ & 0.183 \\
\hline $\mathrm{Mg}^{2+}, \mathrm{mmol} / \mathrm{l}$ & $2.90 \pm 5.30$ & $6.50 \pm 7.90$ & 0.421 \\
\hline $\mathrm{Ca}^{2+}, \mathrm{mmol} / \mathrm{l}$ & $0.90 \pm 1.00$ & $1.10 \pm 0.60$ & 0.757 \\
\hline $\mathrm{PO}_{4}{ }_{4}^{3-}, \mathrm{mmol} / \mathrm{l}$ & $3.90 \pm 1.70$ & $2.70 \pm 1.30$ & 0.125 \\
\hline $\mathrm{Cl}^{-}, \mathrm{mmol} / \mathrm{l}$ & $22.40 \pm 6.50$ & $19.20 \pm 5.80$ & 0.461 \\
\hline $\mathrm{SO}_{4}{ }_{4}^{2-}, \mathrm{mmol} / \mathrm{l}$ & $0.0020 \pm 0.0010$ & $0.0008 \pm 0.0011$ & 0.207 \\
\hline $\mathrm{Zn}^{2+}, \mathrm{mg} / \mathrm{l}$ & $0.04 \pm 0.02$ & $0.04 \pm 0.02$ & 0.464 \\
\hline $\mathrm{Al}^{3+}, \mathrm{mg} / \mathrm{l}$ & $0.0030 \pm 0.0001$ & $0.0030 \pm 0.0001$ & 0.802 \\
\hline
\end{tabular}

Data presented as mean \pm standard deviation

TABLE 2. Molar ratios of chemical analytes in OF, $X \pm m$

\begin{tabular}{|c|c|c|c|}
\hline Molar coefficients & Case group & Control group & $p$-value \\
\hline $\mathrm{Na}^{+} / \mathrm{K}^{+}$ & $0.58 \pm 0.56$ & $0.75 \pm 0.62$ & 0.437 \\
\hline $\mathrm{Na}^{+} / \mathrm{Mg}^{2+}$ & $14.83 \pm 18.23$ & $9.44 \pm 10.06$ & 0.183 \\
\hline $\mathrm{Ca}^{2+} / \mathrm{PO}_{4}^{3-}$ & $0.28 \pm 0.21$ & $0.45 \pm 0.29$ & 0.137 \\
\hline $\mathrm{PO}_{4}^{3-} / \mathrm{Ca}^{2+}$ & $13.95 \pm 21.88$ & $3.09 \pm 1.76$ & 0.115 \\
\hline $\mathrm{Ca}^{2+} / \mathrm{Mg}^{2+}$ & $1.32 \pm 1.73$ & $0.85 \pm 0.97$ & 0.344 \\
\hline $\mathrm{Ca}^{2+} / \mathrm{Cl}^{-}$ & $0.05 \pm 0.06$ & $0.06 \pm 0.03$ & 0.757 \\
\hline $\mathrm{Al} / \mathrm{Zn}$ & $0.008 \pm 0.003$ & $0.009 \pm 0.006$ & 0.629 \\
\hline $\mathrm{Mg}^{2+} / \mathrm{Ca}^{2+}$ & $4.53 \pm 6.09$ & $9.71 \pm 17.00$ & 0.353 \\
\hline $\mathrm{Mg}^{2+} / \mathrm{PO}_{4}^{3-}$ & $0.88 \pm 1.59$ & $3.43 \pm 5.72$ & 0.170 \\
\hline
\end{tabular}

Data presented as mean \pm standard deviation

TABLE 3. Molar ratios of chemical analytes in cervical enamel, $\pm m$

\begin{tabular}{|c|c|c|c|}
\hline $\begin{array}{l}\text { Molar } \\
\text { coefficients }\end{array}$ & Case group & Control group & $p$-value \\
\hline $\mathrm{Na} / \mathrm{K}$ & $55.8706 \pm 41.3412$ & $38.2085 \pm 41.7515$ & 0.071 \\
\hline $\mathrm{Na} / \mathrm{Mg}$ & $10.2195 \pm 14.9372$ & $8.8071 \pm 17.5403$ & 0.706 \\
\hline $\mathrm{Ca} / \mathrm{P}$ & $2.0977 \pm 0.1962$ & $1.8983 \pm 0.1864$ & $<0.001^{*}$ \\
\hline $\mathrm{P} / \mathrm{Ca}$ & $0.4803 \pm 0.0403$ & $0.5313 \pm 0.0473$ & $<0.001^{*}$ \\
\hline $\mathrm{Ca} / \mathrm{Mg}$ & $307.7388 \pm 242.8532$ & $361.8856 \pm 201.7616$ & 0.309 \\
\hline $\mathrm{Ca} / \mathrm{Cl}$ & $92.0273 \pm 33.7824$ & $76.8978 \pm 22.7115$ & $0.032^{*}$ \\
\hline $\mathrm{Al} / \mathrm{Zn}$ & $18.4448 \pm 38.3761$ & $19.8389 \pm 40.4231$ & 0.879 \\
\hline $\mathrm{Mg} / \mathrm{Ca}$ & $0.0042 \pm 0.0019$ & $0.0232 \pm 0.0015$ & $0.018^{*}$ \\
\hline $\mathrm{Mg} / \mathrm{P}$ & $0.0086 \pm 0.0038$ & $0.0060 \pm 0.0026$ & $0.001^{*}$ \\
\hline $\mathrm{K} / \mathrm{Na}$ & $0.0456 \pm 0.0644$ & $0.0911 \pm 0.0982$ & $0.016^{*}$ \\
\hline
\end{tabular}

Data presented as mean \pm standard deviation 
TABLE 4. Correlation between the content of chemical analytes in OF and cervical enamel, $r(p<0.0001)$

\begin{tabular}{|c|c|c|c|c|c|c|c|c|}
\hline Chemical analytes & Group & $\mathbf{K}^{+}$ & Group & $\mathrm{PO}_{4}^{3-}$ & Group & $\mathrm{Na}^{+}$ & Group & $\mathrm{Cl}^{-}$ \\
\hline \multirow[t]{2}{*}{$\mathrm{Ca}^{2+}$} & I & -0.8817 & 1 & 0.9607 & I & -0.6410 & I & -0.8664 \\
\hline & $\|$ & -0.9433 & II & 0.9781 & II & -0.6799 & $\|$ & -0.9125 \\
\hline \multirow[t]{2}{*}{$\mathrm{Na}^{+}$} & I & 0.6343 & \multirow{2}{*}{\multicolumn{2}{|c|}{-}} & \multirow{2}{*}{\multicolumn{2}{|c|}{-}} & 1 & 0.6177 \\
\hline & II & 0.7168 & & & & & $\|$ & 0.6926 \\
\hline \multirow[t]{2}{*}{$\mathrm{PO}_{4}^{3-}$} & I & -0.8727 & \multirow{2}{*}{\multicolumn{2}{|c|}{-}} & I & -0.6288 & 1 & -0.8286 \\
\hline & $\|$ & -0.9545 & & & $\|$ & -0.6601 & $\|$ & -0.9110 \\
\hline \multirow[t]{2}{*}{$\mathrm{K}^{+}$} & \multirow{2}{*}{\multicolumn{2}{|c|}{-}} & \multirow{2}{*}{\multicolumn{2}{|c|}{-}} & \multirow{2}{*}{\multicolumn{2}{|c|}{-}} & 1 & 0.9203 \\
\hline & & & & & & & $\|$ & 0.9388 \\
\hline
\end{tabular}

I- case group, II - control group

$(r=0.5554), \mathrm{K}^{+}(r=0.6570), \mathrm{Na}^{+}(r=0.6463)$; inversely proportional correlation with $\mathrm{Ca}^{2+}(r=-0.5757)$ and $\mathrm{PO}_{4}^{3-}$ $(r=-0.5975), p<0.0001$.

The molar coefficients of the chemical analytes of the cervical enamel and OF in both groups were associated in direct proportion (moderate and high strength): $\mathrm{Ca}^{2+} / \mathrm{P}$ and $\mathrm{Na}^{+} / \mathrm{K}^{+}, \mathrm{Ca}^{2+} / \mathrm{Mg}^{2+}$ and $\mathrm{Ca}^{2+} / \mathrm{P}$, $\mathrm{Ca}^{2+} / \mathrm{Cl}^{-}$and $\mathrm{Na}^{+} / \mathrm{K}^{+}, \mathrm{Ca}^{2+} / \mathrm{Cl}^{-}$and $\mathrm{Ca}^{2+} / \mathrm{P}, \mathrm{Mg}^{2+} / \mathrm{P}$ and $\mathrm{Ca}^{2+} / \mathrm{P}(p<0.0001)$. The distinctive feature of relationships in the control group was the presence of correlation of inversely proportional moderate strength between $\mathrm{Ca}^{2+} / \mathrm{Cl}^{-}$and $\mathrm{P} / \mathrm{Ca}^{2+}(r=-0.5973)$, directly proportional high strength between $\mathrm{Mg}^{2+} / \mathrm{Ca}^{2+}$ and $\mathrm{P} / \mathrm{Ca}^{2+}$ $(r=0.7055)$, and the absence of moderate inversely proportional $\mathrm{Mg}^{2+/} \mathrm{Ca}^{2+}$ with $\mathrm{Ca}^{2+} / \mathrm{PO}_{4}^{3-}(r=-0.5863)$, typical for patients with cervical caries $(p<0.0001)$.

\section{DISCUSSION}

From the mineral metabolism point of view, caries is polyelementosis requiring complex pathogenetic treatment, including the normalization of water-salt, phosphorus-calcium metabolism, antioxidants, and immune status of the body [16]. In the case of a pathology development, the relationship between demineralization and remineralization is influenced by the presence of saliva, which ensures the transport of ions on the surface of teeth [17]. Presumably, mineralization/demineralization affects only the outer layer of the enamel, while deeper layers are not affected by these processes [18]. However, these factors can be explained only by the evaluation of chemical composition of the enamel surface of teeth.

Our study involved patients with resistance to caries process and with compensated form of dental caries $(\mathrm{DMFT}=1.45 \pm 0.48)$. The level of caries resistance is characterized by certain physical and chemical parameters of OF [7]. There is a high concentration of free and ionized calcium, and a relatively low content of phosphate with a high level of caries resistance [19]. An important role in the onset and progression of the identi- fied pathology may play the decrease in calcium molarity, which was identified in patients with cervical caries [17]. The increase in the amount of inorganic phosphates is one of the factors that enhance the remineralizing potential of saliva [8]. We have not observed any significant difference in OF chemical composition in the patients with cervical caries and intact hard tissues like other researchers, which could be caused by the compensated form of caries in the main group $(p>0.05)[17,20]$. At the same time, other researchers have identified a significant decrease in the number of mineral groups in $\mathrm{OF}$ in patients with multiple caries $[17,21]$. They showed reduced concentrations of $\mathrm{K}^{+}, \mathrm{Na}^{+}, \mathrm{Mg}^{2+}, \mathrm{Ca}^{2+}$, and increased concentrations of $\mathrm{PO}_{4}^{3-}, \mathrm{Cl}^{-}$, and $\mathrm{SO}_{4}^{2-}$ in saliva of patients with carious pathology; these results are comparable with that of previous studies $(p<0.05)$ [16].

Taking into account the inter-element of synergy and antagonism as well as the complex influence on various physiological parameters of individual chemical elements, a more sensitive indicator of their relationship is the correlation between the ratios of certain element pairs $[16,22]$. The imbalance in OF chemical composition has led to a decrease of metabolically important calcium-phosphorus ratio in patients with cervical caries [9]. The ratio of $\mathrm{Na}^{+}$and $\mathrm{K}^{+}$influences the rates of calcium counterflows [23]. Probably, this could explain the significantly lower indices of $\mathrm{Na}^{+} / \mathrm{K}^{+}$in the main group $(p \leq 0.05)$ in the present study. The dynamics of $\mathrm{Na}^{+} / \mathrm{K}^{+}$ coefficient characterizes the activity of sympathetic-adrenal system and the state of thyroid gland. A role of thyroid dysfunction in the development of caries, changes in periodontal tissues, and mineralization has been already proven [24]. The frequency and intensity of caries is higher in children with hypothyroidism than in healthy children, on the basis of changes in OFs' physicochemical and structural properties: a decrease in the rate of salivation, an increase in viscosity with a simultaneous growth of the calcium content, and a decrease in the concentration of inorganic phosphate [7, 24].

The changes in the physicochemical parameters of saliva are associated with disruption of OF mineralization pro- 
cesses, which is determined by its mineralization potential [25]. A mineralization potential, value of the dispersion coefficient, and a span of the dispersion of electrical impedance of OF were significantly lower in the patients with cervical caries than in the patients in the control group, which was regarded as the decrease in the intensity of its mineralization, micellarity, and mineralizing ability [14]. Moreover, a mineralization potential correlates with a calcium content of OF [26]. The average indices of mixed saliva mineralization corresponded to its high level in both groups that was explained by participation of patients with resistance to caries process and compensated forms of caries in the study [9]. It has been confirmed that the mineralizing function of saliva changes in case of development of cariogenic situation in the oral cavity, which leads to destabilization of its crystal structure [25].

Teeth enamel with a carious process was characterized by a slightly higher amount of calcium and a lower amount of phosphorus ( $p \leq 0.05$ ), while there was a tendency towards an increase in the amount of magnesium, probably, due to the replacement of a part of calcium atoms in calcium-deficient apatite with magnesium $(p>0.05)[15,22]$. The amount of calcium in the enamel determines its development in different types of pathology [27]. In the enamel of cervical region of all samples, the amount of calcium was in a direct relationship of high strength with phosphorus, which confirms the results of other researchers [27].

The magnesium content decreases with the increase of the calcium content, with its direct correlation [17, 18]. Here, we determined an inverse correlation between calcium, phosphorus, potassium, sodium, and chlorine in the enamel of permanent teeth and OF. Other researchers have found a negative correlation between the concentration of phosphorus, sodium, and magnesium in saliva and enamel of deciduous teeth [22]. In their opinion, it indicates the role of OF as a source of ions and/or reflects complex interelement interactions (for example, functional antagonism of $\mathrm{Ca}^{2+}$ and $\mathrm{P}, \mathrm{Ca}^{2+}$ and $\mathrm{Mg}^{2+}$ ) [22]. Most likely, it is due to the difference in the relationship of saliva and enamel of temporary and permanent teeth.

A number of researchers have determined a strong correlation between the coefficients of $\mathrm{Ca}^{2+} / \mathrm{P}$ and $\mathrm{Ca}^{2+} /$ $\mathrm{Mg}$ in OF and hard tissues of deciduous teeth [22]. In our study, we found a similar relationship between the cervical enamel and mixed saliva of the patients with cervical caries and intact hard tissues. The increase in the molar ratio $\mathrm{Mg} / \mathrm{P}$ in the enamel of the samples with a carious process was the evidence of the partial replacement of calcium with magnesium in the structure of hydroxyapatite [28]. Obtained results show the importance of screening for risk factors for caries development, which begins with the determination of physicochemical parameters of saliva.

\section{CONCLUSIONS}

The imbalance of the physical and chemical parameters of oral fluid affecting the level of its mineralization, their correlation with the chemical composition of the enamel is the background, against which it is possible to predict and suspend the development of carious process. Revealed relationships reflect the features of etiopathogenetic processes in the onset and progression of cervical caries. The obtained results can be used as a non-invasive method in pre-clinical diagnosis of the carious process, and as an objective assessment of the effectiveness of prescribed remineralizing therapy.

\section{CONFLICT OF INTEREST}

The authors declare no potential conflicts of interest with respect to the research, authorship, and/or publication of this article.

\section{References}

1. Gao X, Jiang S, Koh D, Hsu CY. Salivary biomarkers for dental caries. Periodontol 2000 2016; 70: 128-141.

2. Mamaladze M, Khutsishvili L, Zarkua E. Distribution of carious and non-carious cervical lesions and gingival recession at age related aspects. Georgian Med News 2016; 256-257: 18-23.

3. Rizaev JA, Asadullaev NS, Abduvakilov JU. Dynamics of age indicators of physical and chemical structure of oral fluid in elderly and senile people. Visnyk Problem Biolohii i Medytsyny 2018; 3: 382-385.

4. Lukashevich IK, Gorbunova IL. Studying the oral fluid indicators in pregnant women by topical application of three-composition calcium-phosphate-fluorine-containing gel as a caries prophylactics measure. Stomatologiia (Mosk) 2018; 97: 19-22.

5. Gulenko OV, Khagurova SB, Bykov IM. Peculiarities of the physico/biochemical properties of the mouthloid in children with dent carious on the background of psychoneuvrological disorders. RUDN Journal of Medicine 2017; 21: 329-338.

6. Velásquez N, Pérez-Ybarra L, Urdaneta CJ, Pérez-Domínguez M. Sialometry and concentration of phosphate and calcium in stimulated whole saliva and gingival crevicular fluid and its association with dental caries in schoolchildren. Biomedica 2019; 39: 157-169.

7. Razmakhnina EM, Kiseleva EA. Charecteristics of caries resistance levels depending on the properties of oral liquid in residents of Kemerovo. Medicine in Kuzbass 2015; 14: 44-47.

8. Akhmedbeyli R. The level of $\mathrm{Ca}$ and $\mathrm{P}$ content in oral saliva of schoolchildren depending on the length of fluoridated iodized salt intake in conditions of biogeochemical deficiency of fluoride and iodide. Modern Stomatology 2016; 1: 68-70.

9. Tkachenko PI, Kaskova LF, Popelo YV. Correction of speed of salivation and mineralizing potential of the oral fluid in children with malignant tumors of soft tissues, who receive the chemotherapy. Ukrainian Dental Almanac 2015; 5: 65-70.

10. Farooq I, Bugshan A. The role of salivary contents and modern technologies in the remineralization of dental enamel: a narrative review. Version 2. F1000Res 2020; 9: 171

11. Shishniashvili T, Suladze N, Beridze M, Manjavidze N. Biosubstrates as dental health indicators in school-age children. Georgian Med News 2018; 276: 51-55.

12. Martina E, Campanati A, Diotallevi F, Offidani A. Saliva and oral diseases. J Clin Med 2020; 9: 466. 
13. Avramova OG, Ippolitov YuA, Plotnikova YaA, Seredin PV, Goloshapov DV, Aloshina EO. Increased oral fluid remineraling function by endogenous and exogenous saturation methods of its mineral complexes. Stomatologiia (Mosk) 2017: 2: 6-11.

14. Yarova SP, Zabolotna II, Petukhov VV, Kobtseva OA, Reva OP. Comparative analysis of biophysical parameters of oral fluid, depending on the condition of dental hard tissue. Medicine Today and Tomorrow 2019; 3: 23-29.

15. Zabolotna II. Results of quantitative X-ray spectrum analysis of precervical teeth area. Medical Journal 2013; 1: 86-87.

16. Kurov IP, Skalnaya MG. Non-invasive study of indicators of mineral metabolism in young men with caries, chronic periodontitis and sanified mouth. Galician Medical Journal 2013; 20: 130-135.

17. Sejdini M, Meqa K, Berisha N, et al. The effect of Ca and Mg concentrations and quantity and their correlation with caries intensity in school-age children. Int J Dent 2018; 2018: 2759040.

18. Klimuszko E, Orywal K, Sierpinska T, Sidun J, Golebiewska M. Evaluation of calcium and magnesium contents in tooth enamel without any pathological changes: in vitro preliminary study. Odontology 2018; 106: 369-376.

19. Obukhov YA. Local and systemic processes that influence the development of caries in children (the literature review). Pediatric Bulletin of the South Ural 2015; 2: 63-66.

20. Sekhri P, Sandhu M, Sachdev V, Chopra R. Estimation of trace elements in mixed saliva of caries free and caries active children. J Clin Pediatr Dent 2018; 42: 135-139.

21. Seredin PV, Goloshchapov DL, Ippolitov YA, Avraamova OG. Spectroscopic studies of the changes occurring in the molecular composition of oral fluid in people with multiple caries. Stomatologiia (Mosk) 2019; 98: 50-55.

22. Radysh IV, Ordzhonikidze GZ, Grabeklis AR, Papilko IV, Gunter TG. Elemental composition of temporary teeth and mixed saliva in children. Vestnik of OSU 2006; 12-2: 204-207.

23. Domenyuk DA, Davydov BN, Vedeshina EG, Dmitrienko SV, Gilmiyarova FN, Orfanova GS. Alteration of bone tissue metabolism markers in blood serum and oral fluid in patients with dentoalveolar pathologies. The Dental Institute 2015; 4: 98-100.

24. Beriashvili S, Nikolaishvili M, Mantskava M, Momtsemlidze N, Franchuk K. Changes in tooth hard tissue mineralization and blood rheology in healthy adolescents and those with thyroid dysfunction. Georgian Med News 2016; 11: 28-34.

25. Kovalenko VV, Tkachenko IM, Nazarenko ZY, et al. The study of oral fluid dynamic parameters on the background of pathological and physiological dental abrasion. Wiad Lek 2019; 72: 1315 1319.

26. Bel'skaya LV, Sarf EA. The circadian dynamics of composition of human saliva according data of infrared-Fourier-spectroscopy. Klin Lab Diagn 2018; 63: 277-281.

27. Tkachenko IM, Kovalenko VV. Research of microelement composition of enamel and dentine of teeth at caries and increased tooth erosion. Visnyk Problem Biolohii i Medytsyny 2017; 4: 248-252.

28. Srot V, Bussmann B, Salzberger U, Koch CT, van Aken PA. Linking microstructure and nanochemistry in human dental tissues. Microsc Microanal 2012; 18: 509-523. 